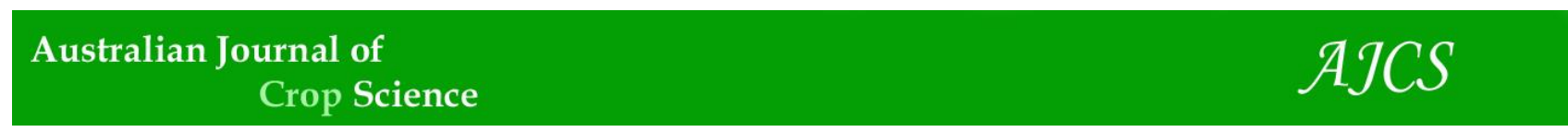

AJCS 12(01):74-80 (2018)

ISSN:1835-2707

doi: 10.21475/ajcs.18.12.01.pne669

\title{
Phytomass of lettuce cultivars under water replenishment levels
}

\author{
Silvanete S. da Silva*, José Dantas Neto, Carlos Alberto Vieira de Azevedo, Juarez Paz Pedroza, Roberto \\ Vieira Pordeus, Claudia Facini dos Reis
}

Federal University of Campina Grande, Academic Unit of Agricultural, Engineering, Campina Grande, CEP 58.109970, Paraíba, Brazil

\section{*Corresponding author: silvanete.h@hotmail.com}

\begin{abstract}
Water scarcity in the semi-arid region causes significant losses in the socioeconomic activities, with reduction in agriculture. Therefore, this study aimed to evaluate the effect of the application of irrigation depths on the phytomass accumulation of lettuce cultivars. The experiment was carried out at the Academic Unit of Agricultural Engineering, in 10 beds composed of 78 plants each, at spacing of $0.25 \times 0.30 \mathrm{~m}$. The treatments were set in a $5 \times 3$ factorial scheme, with five water replacement levels, The irrigation depths were applied based on the reference evapotranspiration - ETo, as follows: $70 \%$ (L1), 80\% (L2), 90\% (L3), 100\% (L4) and 115\% (L5) of the reference evapotranspiration - ETo, and three cultivars: Elba' - C1, 'Iceberg' - C2 and 'Looseleaf' - C3, four replicates. Irrigations were applied through a drip system with the aid of the program ETo calculator-FAO Penman-Monteith to estimate the reference evapotranspiration. The following variables were determined: fresh matter (FM), dry matter (DM), root fresh matter (RFM), root dry matter (RDM), number of leaves (NL) and plant height (PH). According to the results, the increment in irrigation depths increased leaf fresh matter, number of leaves, plant height and root dry matter. The irrigation depth of $192.4 \mathrm{~mm} \mathrm{cycle}{ }^{-1}$, i.e., $100 \%$ of evapotranspiration under field conditions led to greater yield.
\end{abstract}

Keywords: Lactuca sativa L.; Irrigation; Reference evapotranspiration.

Abbreviations: C1_Elba; C2_Iceberg; C3_Looseleaf; ETo_The reference evapotranspiration; FAO_Food and Agriculture Organization of the United Nations; FM_Fresh matter; DM_Dry matter; RFM_Root fresh matter; RDM_Root dry matter; NL_Number of leaves; $\mathrm{PH} \_$plant height; $\mathrm{mm}$ day ${ }^{-1}{ }^{-}$Millimeter per day; ns_Not significant; ${ }^{* *}$ _significant at 0.01 probability; ${ }^{*}{ }_{\text {_tignificant }}$ at 0.05 probability. DF_Degree of freedom; C.V_Coefficient of variation; g plant ${ }^{-1}$ Grass per plant; $\mathrm{Kg}^{-1}$ - Per kilogram; pH_Hydrogen potential; Ca_Calcium; $\mathrm{Cmol}_{\mathrm{C}}$ Loading centimeter; $\mathrm{Mg}$ _ magnesium; Na_sodium; $\mathrm{K} \_$Potassium; $\mathrm{H}+\overline{\mathrm{Al}}$ _Hydrogen and aluminum; OM_Organic matter; P_Phosphor; PVC_Polyvinyl chloride; INMET_The National Institute of MeteorologY; M_Meters; M $^{2}$ Square meters.

\section{Introduction}

Lettuce is a plant native to regions with temperate climate and cannot be cultivated under conditions of high temperature and luminosity, because they compromise its genetic potential and favor the reduction of the cycle (Cruz et al., 2011), so that climatic factors directly interfere with the production potential of this vegetable.

The evapotranspiration of the lettuce crop, according to Cunha et al. (2013), normally exceeds the rainfall and, consequently, the adequate distribution of water through irrigation has been the guarantee to maximize the production without altering the previously established levels of yield and profitability, in case of scarcity of rainfalls.

In the Northeast region of Brazil, lettuce is usually cultivated using irrigation, with a drip or hydroponic system, fertilization and exploited in family farming. Santos et al. (2011), studying the production in the microregion of 'Brejo Paraibano', found that the lettuce crop is one of the main produced vegetables and has economic and social importance, being commercialized especially in markets of the region. For Assunção (2013), the production of vegetables promotes the maintenance of 3 to 6 direct jobs and the same number of indirect jobs (per hectare), serving as a means of subsistence.

For Zárate et al. (2010), lettuce production depends on the interaction between genotypes and the climate of the region. On the other hand, water is directly involved in the physiological processes, such as: solvent, reagent, maintenance of molecular structures, maintenance of turgor and thermal regulation of the plant tissues (MorenoFonceca, 2009). It is known that water excess can cause decrease in the oxygen pressure (hypoxia) or its lack (anoxia) in the soil, which will hamper plant respiration (Moreira et al., 2009).

Therefore, this study aimed to evaluate the effect of irrigation depths on the agronomic performance of lettuce cultivars, to guide the producers of this vegetable in the selection of varieties that exhibit acceptable agronomic features in the local market. 


\section{Results and Discussion}

\section{Total water consumption}

The ETo values daily estimated along the crop cycle are presented in Figure 1. The ETo was lower in the beginning of the experiment and the mean values in June, July and August were equal to $4.5,5.0$ and $5.7 \mathrm{~mm}$, respectively. The maximum means of daily water replacement, per treatment, were: $\mathrm{L} 1=3.34 \mathrm{~mm}$ day $^{-1} ; \mathrm{L} 2=3.85 \mathrm{~mm}^{-1}{ }^{-1} ; 4.33 \mathrm{~mm}$ day ${ }^{1}$; $\mathrm{L} 4=4.81 \mathrm{~mm}$ day $^{-1}$ and $\mathrm{L} 5=5.54 \mathrm{~mm} \mathrm{day}^{-1}$. The total water consumption by the lettuce plants in the entire cycle was $876.03 \mathrm{~mm}$.

\section{Phytomass of lettuce cultivars}

According to the summary of the analysis of variance (Table 1 ), there was a significant effect on the cultivars ('Elba', 'Looseleaf' and 'Iceberg'), individually by $F$ test for all analyzed variables, except root dry matter; however, there was a non-significant effect on the variable fresh matter in the source of variation irrigation depths. There were significant effects on plant height, root dry matter and root fresh matter $(p \leq 0.01)$ and on number of leaves and dry matter $(p \leq 0.05)$.

As to the follow-up analysis of the irrigation depths in relation to the cultivars, the irrigation depths caused a polynomial effect on the PH of the cultivars 'Elba' and 'Looseleaf', and linear effect on 'Iceberg', with similar values for the irrigation depths of 168.46 and $167.54 \mathrm{~mm}(87.56$ and $87.08 \%$ ETo), concomitantly, which maximized plant height, with mean values of 19.94 and $19.91 \mathrm{~cm}$ ('Elba' and 'Looseleaf'). On the other hand, the cultivar 'Iceberg' obtained height of up to $19.81 \mathrm{~cm}$ when $70 \%$ ETo was applied, i.e., $133.6 \mathrm{~mm}$ (Figure 2A), which thus demonstrates a lower performance of water consumption by this cultivar. The irrigation depths caused polynomial effect on the dry matter (Figure 2B) of the cultivars 'Iceberg' and 'Looseleaf'. The irrigation depth of $111.33 \%$ ETo $(214.20 \mathrm{~mm})$ increased by up to $4.98 \mathrm{~g}$ the dry matter of the cultivar 'Looseleaf', while $113.40 \%$ ETo $(218.18 \mathrm{~mm})$ increased the dry matter of the cultivar 'Iceberg' by $4.87 \mathrm{~g}^{\text {plant }}{ }^{-1}$. On the other hand, the cultivar 'Elba' showed an increasing linear effect, with maximum point of $5.09 \mathrm{~g}$ plant $^{-1}$ for the irrigation depth of $221.6 \mathrm{~mm}$ (115\% ETo) and minimum point of $3.96 \mathrm{~g} \mathrm{plant}^{-1}$ for the water replacement of $133.6 \mathrm{~mm}$ (70\% ETo).

Lima Júnior et al. (2010) studied the 'Iceberg' lettuce under different irrigation depths and observed that the maximum commercial yield was estimated for the application of the irrigation depth of $164.8 \mathrm{~mm}$, corresponding to the replacement factor of $98 \%$; however, the temperatures in the experimental area were in adequate conditions for the type of cultivar. According to Santana et al. (2009), the adequate temperature range for the good development of lettuce is between 15 and $20{ }^{\circ} \mathrm{C}$, which are much lower than the temperatures found in the present study.

The effect of the irrigation depths on the number of leaves of the lettuce cultivars was similar to that on plant height, i.e., polynomial effect for the cultivars 'Elba' and 'Looseleaf' (Figure 2C). Thus, the irrigation depths with 94.74 and 94.34\% ETo (182.28 and $181.51 \mathrm{~mm}$ ) promoted gains of
14.82 and 15.22 units in the number of leaves for the cultivars 'Elba' and 'Looseleaf', respectively. For the cultivar 'Iceberg', the effect was linear, with maximum of 14.68 units $(221.6 \mathrm{~mm})$ and minimum of 13.61 units $(133.6 \mathrm{~mm})$. Similar results were found by Araújo et al. (2010), who applied different irrigation depths in 'Verônica' lettuce, in Boa VistaRR.

Regarding the number of leaves, regardless of the irrigation levels, the highest means were observed in the cultivars 'Iceberg' (14.87 leaves plant ${ }^{-1}$ ) and 'Looseleaf' (14.85 leaves plant ${ }^{-1}$ ), which did not differ statistically, while the lowest mean was observed in the cultivar 'Elba' (13.12 leaves plant ${ }^{-1}$ ) (Figure 3A). Plant height (Figure 3B) showed different results between the cultivars, when analyzed individually. The highest values of plant height occurred in the cultivars 'Looseleaf' $(20.40 \mathrm{~cm})$ and 'Elba' $(18.60 \mathrm{~cm})$, while the lowest ones occurred in the cultivar 'Iceberg' $(17.20 \mathrm{~cm})$.

Regarding the dry matter (Figure $3 \mathrm{C}$ ), the values did not differ. Individually, the highest values occurred in the cultivars 'Looseleaf' ( $4.90 \mathrm{~g}$ plant $\left.{ }^{-1}\right)$, then 'Elba' ( $4.77 \mathrm{~g}$ plant $\left.{ }^{1}\right)$ and, lastly, 'Iceberg' (4.26 g plant $\left.^{-1}\right)$.

For fresh matter (Figure 3D), there was significant difference only for the cultivar 'Iceberg' (115.81 $\mathrm{g} \mathrm{plant}^{-1}$ ), while the cultivars 'Looseleaf' (78.70 $\mathrm{g} \mathrm{plant}^{-1}$ ) and 'Elba' (81.97 g plant $^{-1}$ ) did not differ statistically.

The quadratic effect of the application of irrigation depths (Figures $4 \mathrm{~A}, \mathrm{~B}$ and $\mathrm{C}$ ) showed increase in the number of leaves, plant height and dry matter of lettuce, with the increase in the amount of water, specifically for the irrigation depths of 95.10, 87.33 and 98.12\% ETo (182.97, 160.02 and $188.78 \mathrm{~mm}$ ), respectively. The maximum value for number of leaves (15 leaves) occurred between the irrigation depths of 90 and 100\% ETo (173.2 and $192.4 \mathrm{~mm}$ cycle $^{-1}$ ), and lastly, the dry matter, which increased at the irrigation depth of $98.12 \%$ ETo, reaching maximum value of $0.65 \mathrm{~g} \mathrm{plant}^{-1}$, equivalent to $188.78 \mathrm{~mm}$.

Similar results were found by Lima Júnior et al. (2010), with quadratic response of the number of leaves for the application of the irrigation depth of $101 \%$ of water replacement. On the other hand, Magalhães et al. (2015) found similar values (14 leaves per plant) for the irrigation depth of up to $266.37 \mathrm{~mm}$ for different cultivars of the 'Looseleaf' type.

According to Figure 4, root dry matter suffered a decreasing linear effect of the applied irrigation depths, at 0.01 probability level. The increase in the irrigation levels promoted a reduction in root dry matter, i.e., the values were inversely proportional; the minimum irrigation depth led to values of up to $4.96 \mathrm{~g} \mathrm{plant}^{-1}$ and the maximum irrigation depth led to $3.94 \mathrm{~g} \mathrm{plant}^{-1}$. It was observed that $97.96 \%$ of the variations in root dry matter due to the irrigation depths are explained by the linear regression.

\section{Materials and Methods}

\section{Location of experiment}

The experiment was carried out from June to August 2016, in a field area belonging to the Academic Unit of Agricultural Engineering of the Federal University of Campina Grande-PB, 
Table 1. Summary of the analysis of variance and mean squares for number of leaves (NL), plant height (PH), fresh matter (FM), dry matter (DM), root fresh matter (RFM) and root dry matter (RDM) of lettuce cultivated under different irrigation depths. Campina Grande-PB, Brazil, 2016.

\begin{tabular}{|c|c|c|c|c|c|c|c|}
\hline \multirow[b]{2}{*}{ Source of variation } & \multirow[b]{2}{*}{ DF } & \multicolumn{6}{|c|}{ Mean square } \\
\hline & & $\mathrm{NL}$ & $\mathrm{PH}$ & FM & DM & RDM & RFM \\
\hline Cultivar & 2 & $40.26^{* *}$ & $103.48^{* *}$ & $16890.95^{* *}$ & $60.80^{* *}$ & $4.50^{\mathrm{ns}}$ & $0.0034^{\mathrm{ns}}$ \\
\hline $\mathrm{I} \times \mathrm{C}$ & 8 & $22.93^{* *}$ & $12.66^{* *}$ & $543.78^{\mathrm{ns}}$ & $4.33^{*}$ & $1.26^{\mathrm{ns}}$ & $0.1250^{\text {ns }}$ \\
\hline Residual & 105 & 5.93 & 4.28 & 821.05 & 1.81 & 2.15 & 0.0881 \\
\hline CV\% & & 17.05 & 11.04 & 31.09 & 30.03 & 31.57 & 44.56 \\
\hline
\end{tabular}

${ }^{\text {ns }}$ not significant by F test; " significant at 0.01 probability level by $\mathrm{F}$ test; " significant at 0.05 probability level by $\mathrm{F}$ test.

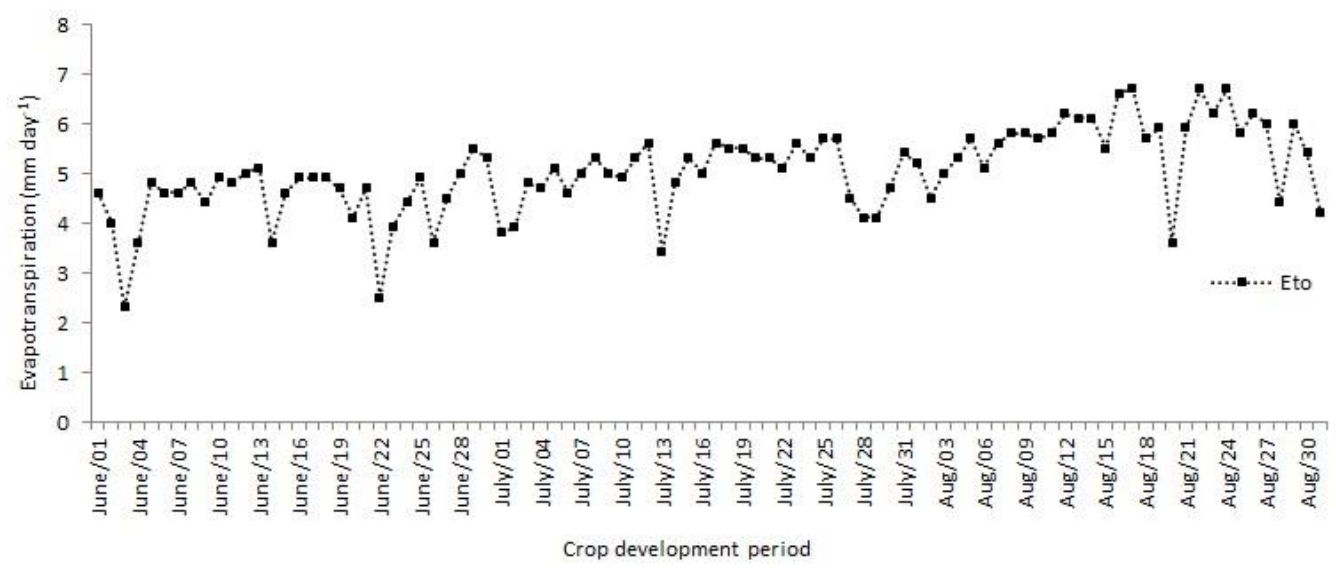

Fig 1. Daily variation of reference evapotranspiration $\left(\mathrm{mm} \mathrm{day}^{-1}\right)$, under the climatic conditions of Campina Grande-PB, Brazil.

(A)

$25\urcorner$

)

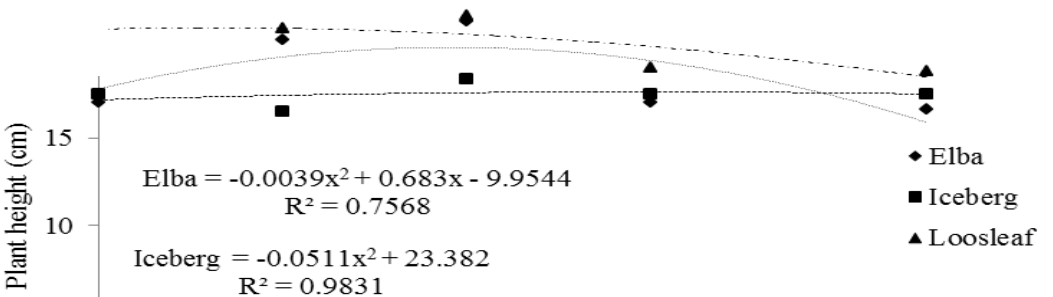

(B)

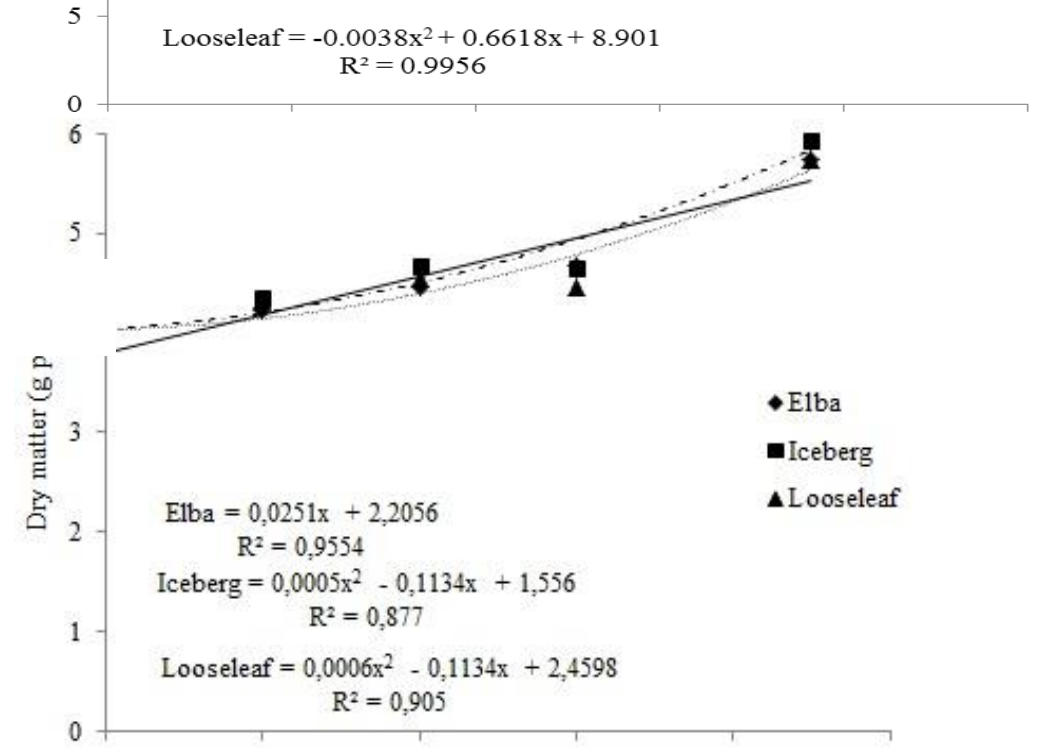




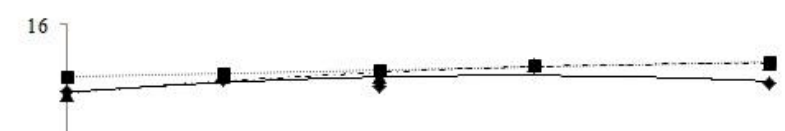

(C)

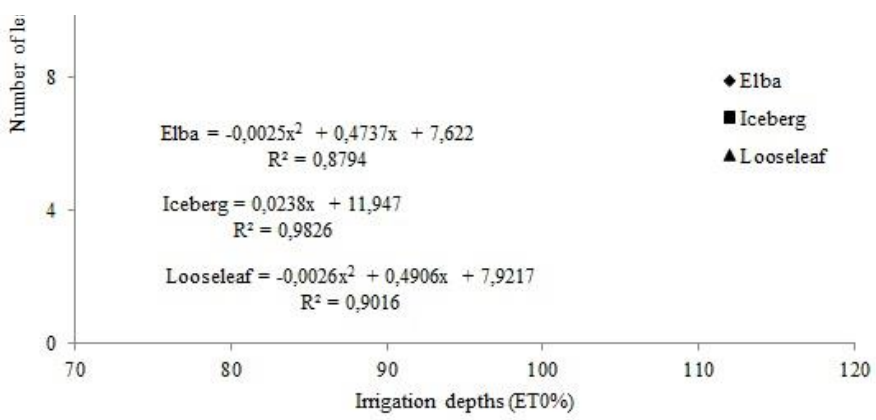

Fig 2. Plant height (A), dry matter (B) and number of leaves per plant (C) of lettuce cultivars subjected to different irrigation depths.
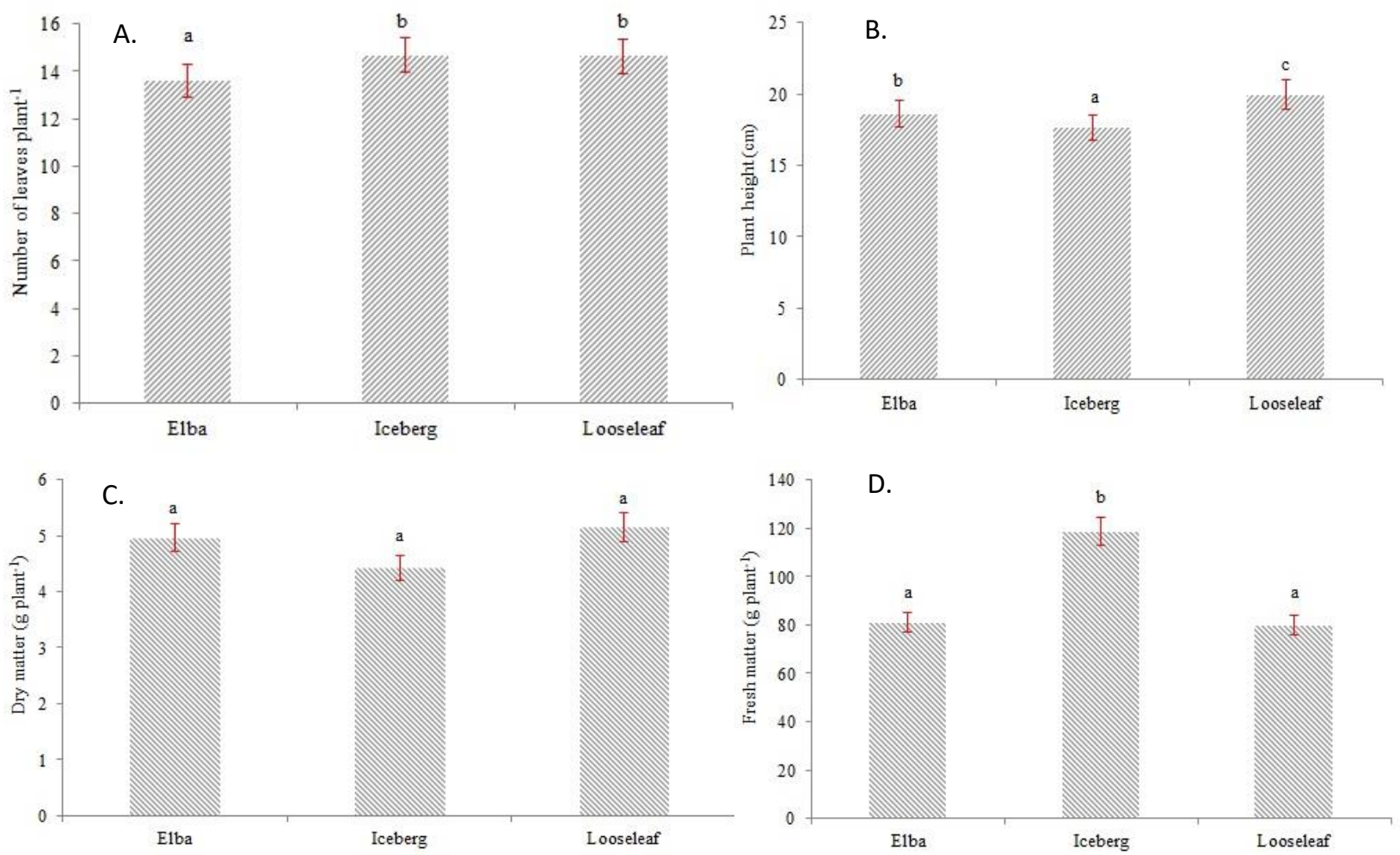

Fig 3. Number of leaves (NL) (A), plant height (PH) (B), fresh matter (FM) (C) and dry matter (DM) (D) of lettuce cultivars subjected to different irrigation depths. The averages differ by no overlap of bars of their respective confidence intervals $(p<0.05)$ 
(A)

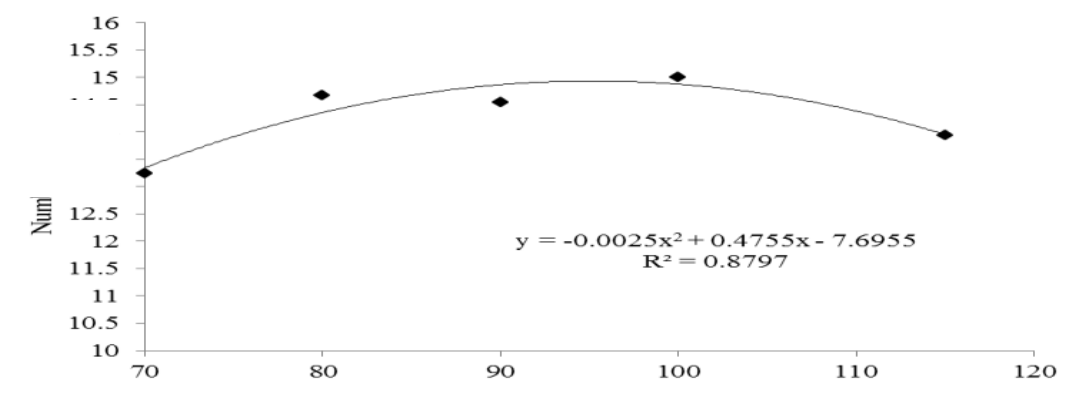

(B)

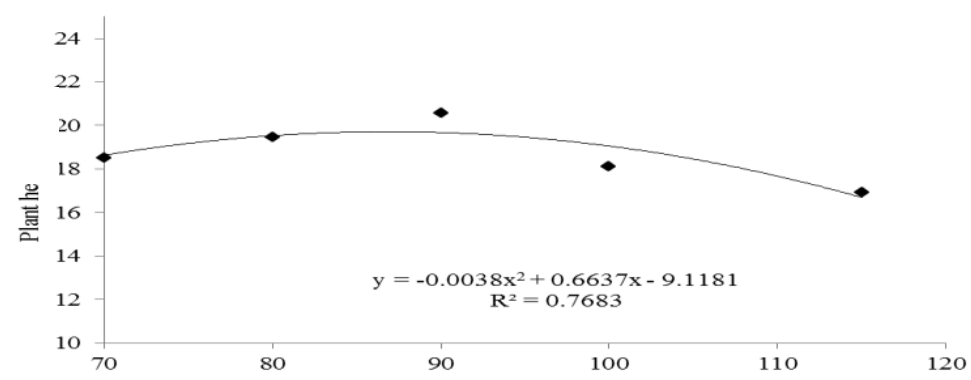

(C)

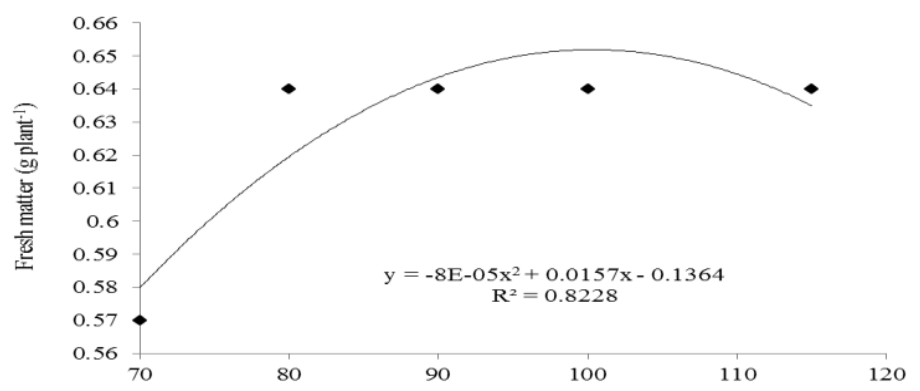

(D)

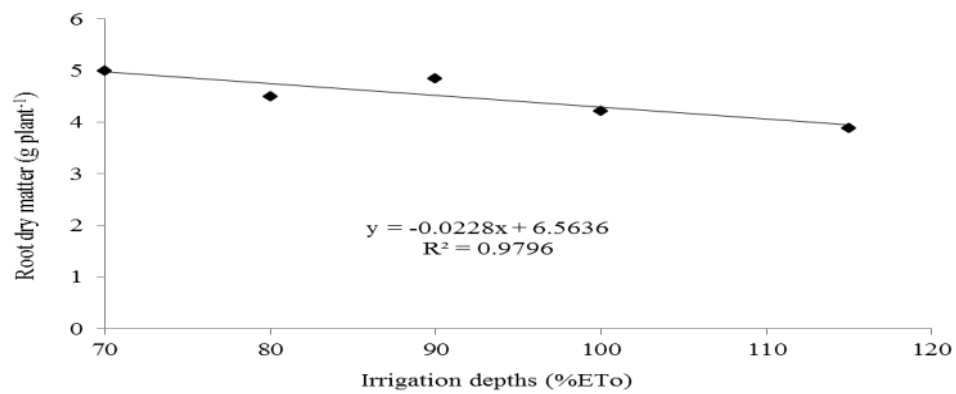

Fig 4. Growth variables of lettuce cultivars as a function of the percentage of reference evapotranspiration: (A) number of leaves $\mathrm{NL}$; (B) plant height - $\mathrm{PH}$; (C) fresh matter - FM and (D) root dry matter - RDM.

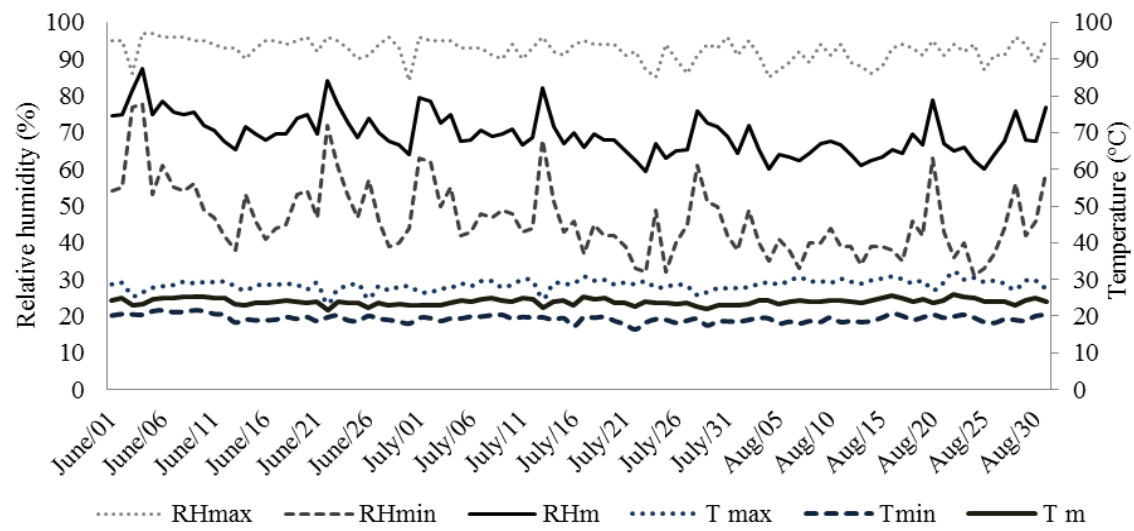

Fig 5. Daily variation of relative air humidity (\%) and temperature $(\stackrel{\circ}{-C})$, under the climate conditions of Campina Grande-PB, Brazil. 

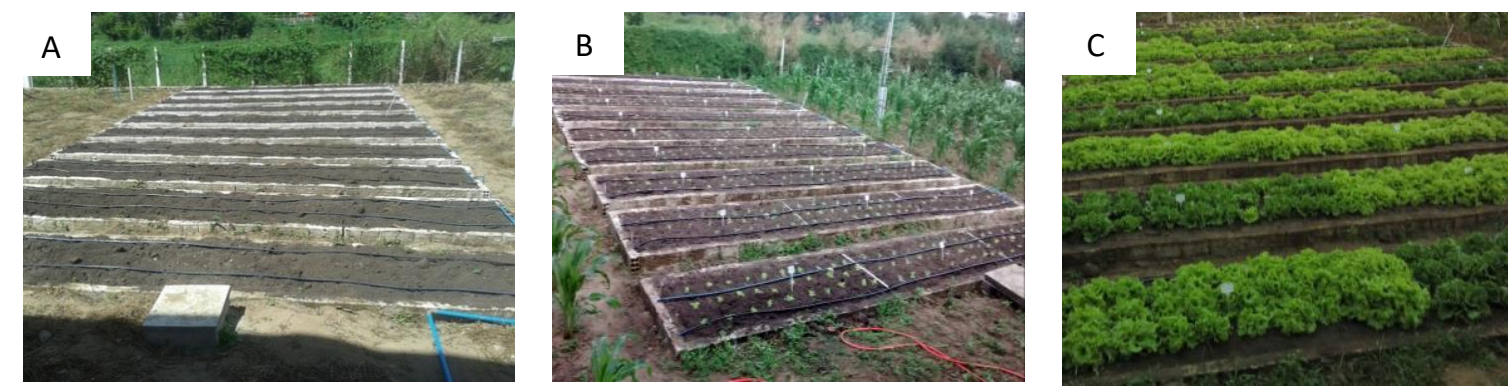

Fig 6. View of the experimental area: layout of the beds and distribution of the irrigation system (A); mounted experiment (B); and lettuce production (C), installed with application of irrigation depths.

with the following geographic coordinates: $07^{\circ} 15^{\prime} 18^{\prime \prime} S$, $35^{\circ} 52^{\prime} 28^{\prime \prime} \mathrm{W}$ and altitude of $550 \mathrm{~m}$. According to the Köppen's classification, the climate of the municipality of Campina Grande is Csa, which represents a mesothermal climate, sub-humid, with hot and dry drought period (4 to 5 months) and rainy period from autumn to winter (Coelho; Soncin, 1982).

\section{Characterization and preparation of the area}

The meteorological elements evaluated during the lettuce cycle are presented in Figure 1. The daily mean values of temperature ranged from 21.5 to $26.0{ }^{\circ} \mathrm{C}$, while those of relative air humidity ranged from 59.5 to $87.5 \%$.

Soil physical and chemical characteristics were analyzed before cultivation at the Laboratory of Irrigation and Salinity (LIS) of the UFCG, using soil samples collected in the superficial layer $(0-20 \mathrm{~cm})$ of a Neosol. The samples were air-dried and passed through a sieve (5-mm mesh). Subsamples were then collected and passed through a 2mm-mesh sieve and subjected to physical and chemical characterization according to the methods adopted by Embrapa (2011), showing the following results: $\mathrm{pH}\left(\mathrm{H}_{2} \mathrm{O}\right)=$ 7.1; $\mathrm{Ca}=1.92 \mathrm{cmol}_{\mathrm{c}} \mathrm{kg}^{-1} ; \mathrm{Mg}=1.44 \mathrm{cmol}_{\mathrm{c}} \mathrm{kg}^{-1} ; \mathrm{Na}=0.16$ $\mathrm{cmol}_{\mathrm{c}} \mathrm{kg}^{-1} ; \mathrm{K}=0.19 \mathrm{cmol}_{\mathrm{c}} \mathrm{kg}^{-1} ; \mathrm{H}+\mathrm{Al}=0 \mathrm{cmol}_{\mathrm{c}} \mathrm{kg}^{-1}$; Sum of bases and Cation exchange capacity $=3.71 \mathrm{cmol}_{\mathrm{c}} \mathrm{kg}^{-1} ; \mathrm{OM}=$ $4.8 \mathrm{~g} \mathrm{~kg}^{-1} ; \mathrm{P}=14.3 \mathrm{mg} \mathrm{kg}^{-1}$; sand $=575.0 \mathrm{~g} \mathrm{~kg}^{-1}$; silt $=50.5 \mathrm{~g}$ $\mathrm{kg}^{-1} ;$ clay $=375 \mathrm{~g} \mathrm{~kg}^{-1}$.

Based on the results of the soil chemical analyses, fertilization at planting consisted in the application of $40 \mathrm{~kg}$ $\mathrm{ha}^{-1}$ of $\mathrm{N}, 60 \mathrm{~kg} \mathrm{ha}^{-1}$ of $\mathrm{P}_{2} \mathrm{O}_{5}$ and $30 \mathrm{~kg} \mathrm{ha}^{-1}$ of $\mathrm{K}_{2} \mathrm{O}$, using urea, single superphosphate and potassium chloride as sources, respectively, according to the methodology of EMBRAPA (2011).

The lettuce crop was sown on plastic trays of 54 cells with disposable cups, under conditions of protected environment, using commercial substrate. The transplantation of seedlings to the definitive place was performed when they showed four true leaves.

The experiment was installed in 10 brickwork beds $(0.25 \mathrm{~m}$ high, $1 \mathrm{~m}$ wide and $8.1 \mathrm{~m}$ long) spaced by $1 \mathrm{~m}$ (Figure 2). Each bed was subdivided using sand dikes into six plots of $1.35 \mathrm{~m}^{2} .15$ plants were transplanted to each plot, spaced by $0.25 \mathrm{~m}$ between rows and $0.30 \mathrm{~m}$ between plants.

\section{Treatments used in this study}

The adopted statistical design was randomized blocks in a 3 x 5 factorial scheme, corresponding to 3 cultivars and 5 irrigation depths, with four replicates. The following cultivars were studied: 'Elba' - C1, 'Iceberg' - C2 and 'Looseleaf' - C3. The irrigation depths were applied based on the reference evapotranspiration - ETo, as follows: 70\% (L1), 80\% (L2), $90 \%(L 3), 100 \%$ (L4) and $115 \%$ (L5) of the reference evapotranspiration - ETo.

The reference evapotranspiration (ETo) was daily estimated by the standard method of Penman-Monteith recommended by FAO (Allen et al., 1998), whose details are presented in Silva et al. (2005). The data to estimate ETo were provided by the National Institute of Meteorology (INMET).

\section{Model of irrigation system}

A drip system was used to irrigate the plants, with two drip tapes per bed, emitters spaced by $0.30 \mathrm{~m}$ and flow rate of 2 $\mathrm{L} \mathrm{h}^{-1}$ at the service pressure of $98 \mathrm{KPa}$. The irrigation system, operated through a motor pump system, consisted of a tank with capacity for $12 \mathrm{~m}^{3}$, main line (PVC, diameter of $32 \mathrm{~mm}$ ), disc filter and glycerin-filled manometer.

\section{Determination of drip}

The irrigation depth applied in each treatment (LT) was obtained using the equation 1 . The $t$ value corresponded to the applied water replacement rate $(L 1=0.7 ; \quad L 2=0.8$; $L 3=0.90$; $L 4=1.00$ and $L 5=1.15$ ) and the $K c$ values were 0.45 in the 20 days after transplantation (DAT) and 0.95 until harvest, following the recommendations of (Marouelli et al., 1996).

$\mathrm{LT}=\mathrm{t} \mathrm{ETo} \mathrm{Kc}$

Where: $\mathrm{t}$ is the water replacement rate, decimal; ETo is the daily reference evapotranspiration, $\mathrm{mm}$; $\mathrm{Kc}$ is the crop coefficient, decimal.

The values obtained through equation 1 , transformed into meters, were multiplied by $8.1 \mathrm{~m}^{2}$, the area of each bed, to find the volume to be applied in liters. The time of operation of the emitters, in each treatment, was obtained by the ratio between the necessary volume and the sum of the flow rates applied by the emitter in each bed.

\section{Measurements}

Harvest was performed at 40 DAT, when plants reached their maximum vegetative development, and the following parameters were evaluated: plant height $(\mathrm{cm})$, leaf area $(\mathrm{cm})$, number of leaves per plant and fresh and dry matters of shoots $\left(\mathrm{g} \mathrm{m}^{-2}\right)$ and roots $\left(\mathrm{g} \mathrm{m}^{-2}\right)$. Plant height was 
determined using a ruler with accuracy of $1 \mathrm{~mm}$. Dry matter was determined using the precision scale; then, the fresh material was placed in paper bags and dried in a forced-air oven at temperature of $65 \pm 5 \stackrel{\circ}{\circ}$ until constant weight, to quantify the dry matter of shoots and roots (g plant ${ }^{-1}$ ), weighed on analytical scale.

The obtained data were evaluated through analysis of variance by $\mathrm{F}$ test at 0.05 and 0.01 probability levels and, in case of significance, linear and quadratic polynomial regression analyses were applied, using the statistical program SISVAR-ESAL (Ferreira, 2014).

\section{Conclusions}

The number of leaves (NL), plant height $(\mathrm{PH})$, fresh matter (FM) and dry matter (DM) were influenced by the different cultivars. Plant height (PH), dry matter (DM), root dry matter (RDM) and number of leaves (NL) were influenced by the different irrigation depths. Number of leaves, plant height and dry matter were influenced by the treatments. The irrigation depth of $192.4 \mathrm{~mm}$ cycle $^{-1}$, i.e., $100 \%$ of evapotranspiration under field conditions led to greater yield. The cultivars 'Iceberg' and 'Looseleaf' showed better performance, in comparison to the cultivar 'Elba'.

\section{Acknowledgements}

The authors would like to thank the Coordination for the Perfectioning of Higher Level Personnel (CAPES) for granting the scholarship to the first author and the Federal University of Campina Grande for approval of the project.

\section{References}

Allen RG, Pereira LS, Raes D, Smith M (1998) Crop evapotranspiration: Guidelines for computing crop water requirements. Rome: FAO. 300 p. (FAO - Irrigation and Drainage Paper, 56).

Araújo TS, Fideles Filho J, Kumar KL, Rao TVR (2010) LettuceAmerican growth according to environments, times and degrees-days. Rev Bras de Ciências Agrárias. V 5. n. 4, p. 441-449. Recife, PE.

Assunção PEV (2013) Expenditures and economic feasibility of the production of pepper in the south of Goiás. Rev Política Agrícola, v.22, p.110-118.

Coelho MA, Soncin NB (1982) Geography of Brazil. São Paulo: Moderna, 368p.

Cruz TP, Junger LA, Zinger LKCR, Silva LG, Passos RR (2011) Evaluation of lettuce cultivars in the municipality of Alegre
- ES. Latin American Meeting of I. L. Scientific initiation, 15. Latin American Meeting of Graduate Studies, Urbanova. Abstracts, p.3.

Cunha FF, Godoy AR, Magalhães FF, Castro MA, Leal AJF (2013) Irrigation of different cultivars of arugula in the northeast of Mato Grosso do Sul. Water Resources and Irrigation Management, v.2, p.131-141.

EMBRAPA - Empresa Brasileira de Pesquisa Agropecuária (2011) National Soil Research Center. Manual of methods of soil analysis. 2 ed Rio de Janeiro: EMBRAPA Soil, 230p.

Doorenbos J, Kassan AH (1979) Yield response to water. FAO. Irrig. and Drain. Paper 33, 193p.

Ferreira DF (2011) SISVAR: A Computer Statistical Analysis System. Ciência e Agrotecnologia (UFLA), v. 35, n.6, p. 1039-1042.

Lima Júnior JA, Pereira GM, Geisenhoff LO, Vilas Boas RC, Silva WGda, Silva LPda (2012) Productivity of American lettuce submitted to different irrigation drip. Semin: Ciências Agrárias. Vol. 33, n. 65.

Mantovani EC, Bernardo S, Palaretti LF (2009) Irrigation: Principles and methods. 2 ed. Viçosa, MG: UFV. 355 p.

Moreno-Fonceca LP (2009) Response of plants to stress due to water deficit. A review. Agronomia Colombiana, Bogotá, v. 27, n. 2, p. 179-191.

Moreira LG, Viana TVA, Marinho AB, Nobre JGA, Lima AD, Alburquerque AHP (2009) Effects of different irrigation drips on the productivity of the castor variety IAC Guarani. Rev Bras de Ciências Agrárias, v. 4, n. 4, p. 449-455.

Marouelli WA, Silva WLC, Silva HR (1996) Management of irrigation in vegetables. Brasília: EMBRAPA-SPI/EMBRAPA$\mathrm{CNPH}, 72 \mathrm{p}$.

Santana CVS, Almeida AC, Turco SHV (2009) Performance of American lettuce cultivars in shaded environments in the sub-region São Francisco-BA. Caatinga, Mossoró, v. 22, n. 4, p. 60-64.

Santos D, Mendonça RMN, Silva SM, Espínola JEF, Souza AP (2011) Commercial production of lettuce cultivars in Bananeiras. Horticultura Brasileira, Vitória da Conquista, v.29, n.4, p.609-612.

Silva VPR, Belo Filho AF, Silva BB, Campos JHBC (2005) Development of a reference evapotranspiration estimation system. Rev Bras de Engenharia Agrícola e Ambiental, Campina Grande, v.9, n.4, p.547-553.

Zárate NAH, Vieira MC, Helmich M, Heid DM, Menegati CT (2010) Agroeconomic production of three varieties of lettuce: cultivation with and without heaping. Ciência Agronômica, Fortaleza, v.41, n.4, p.646-653. 